\title{
Historical insights into British, Japanese and US general science from the first half of the twentieth century
}

Tetsuo Isozaki

Correspondence: isozaki@hiroshima-u.ac.jp Graduate School of Education, Hiroshima University, 1-1-1 Kagamiyama, Higashi-Hiroshima City, Hiroshima Prefecture 739-8524, Japan

\begin{abstract}
Historically, science at the secondary education level has been taught through separate sciences. However, there has been some conflict between the separate sciences and balanced science. In this research, the triangulation of cultures in historical context approach between the United States, the United Kingdom, and Japan was used to analyze the nature and the development of general science as humanized science study in the first half of the twentieth century. Through this examination, historical and fundamental question emerged: what can we learn from the history of general science in the three countries?

This case study of general science can prompt us to reconsider why science is taught, which of its forms are best suited to producing citizens well-informed about science, and how to humanize science without comprising the academic respectability required by professional communities.
\end{abstract}

\section{Introduction}

Historically science education, (in Japan known as "rika" in Japanese (Ogawa 2015)), at the secondary (or post-compulsory) level has primarily been taught through the separate sciences. This approach was favored because some aspects of secondary education are directly related to institutions of higher education which provide professional courses. Accordingly, secondary science (particularly in senior high or upper secondary schools) is frequently a prerequisite for continuing one's education. Secondary science teachers are generally specialists, who have sometimes been characterized and criticized as "divisive and insular" (Young and Glanfield 1998), however, conflicts have arisen between specialists and generalists who advocate separate and balanced sciences, respectively. General science is a form of balanced science that emerged as an introductory subject in secondary schools during the twentieth century in the United States and the United Kingdom (primarily England and Wales), as well as in Japan, where it was dubbed "ippan rika". In this paper, the term "general science" directly means the nature of the subject in secondary schools. On the other hand, the general science "movement" is used as the developmental process and background of organizing the subject.

This paper examines the nature and the development of general science in the three counties by employing a comparative historical (Briggs 1972), namely the triangulation

(c) 2016 Isozaki. Open Access This article is distributed under the terms of the Creative Commons Attribution 4.0 International License (http://creativecommons.org/licenses/by/4.0/), which permits unrestricted use, distribution, and reproduction in any medium, provided you give appropriate credit to the original author(s) and the source, provide a link to the Creative Commons license, and indicate if changes were made. 
of cultures approach (Kawada 2001, 2006, 2008; Hirakawa 2010). The comparative historical approach and the triangulation of cultures approach are the art of investigations by the comparison. The former one is the comparison on historical relations between cultures (countries) in continuity. The latter one is the comparison between three cultures (countries) "in discontinuity, where the fundamental meanings of cultural items might be discovered by this 'heuristic' method" (Kawada 2006, p. 346). Science education is one of the historical activities of the human mind and intellect. Therefore, it can be regarded as one of human cultures. The author has tried to integrate these approaches in order to avoid narrow interpretation of human cultures between three countries. In doing so, the focus is placed on certain general science characteristics in order to highlight fundamental issues regarding secondary level science education from a historical perspective. Japanese science education has been substantially influenced from the West, especially the United States and the United Kingdom, since the midnineteenth century when Japan underwent a period of modernization (Isozaki 2014). As the level of government intervention in the field of education in both the United States and the United Kingdom has traditionally been weaker than Japan, the role of Japanese science educators (that is school teachers, academics, and scientists) has been important in the evolution of science education. Using the triangulation of cultures approach in historical context, the objective measurement that is more appropriate than inter-comparison between two cultures is enabled with two cultures as a reference point to measure a third, in other words such approach can make it possible to relativize and objectify one's standpoint as well as the other two cultures by taking the two others as points of reference (Kawada 2001, 2006, 2008). The case study of general science will show one possible answer to the fundamental question; what can we learn from the history of science education?

\section{Socio-cultural contexts of general science movement}

According to William L. Eikenberry (1871-1953) (1922), the general science movement began in the United States during the last quarter of the nineteenth century. However, George E. DeBoer (1991) argues that it happened during the first quarter of the twentieth century. General science emerged in the early twentieth century in the United Kingdom (Jenkins 1979) for secondary schools for boys and later for girls, and in 1931 in Japan among the middle schools (which means boys' secondary schools). Unlike in the US and the UK, the introduction of general science in Japan did not involve a great deal of debate with respect to its implementation.

The social contexts from which general science arose in these countries were similar: social change was occurring, the progressive education had gained momentum, and the number of secondary students had increased. The last decades of nineteenth century were called a "second" industrial revolution in modern industrial nations (e.g., Hobsbawm 1999). From the late 1880s to about 1930s in Japan, Shmuel N. Eisenstadt (1996) pointed out that in this period "far-reaching social and economic changes attendant on urbanization and industrialization" (p. 86) progressed, and such changes were similar to "other modern industrial nations" (p. 50). In Taisho era (1912-1926), industrial society came about to due to the development of capitalism, on the other hand, the liberalism and democracy grew up that called "Taisho democracy" in Japan. But, after 
World War I, the worldwide economic recession that began in the late 1920s, as well as leading to increased militarism influenced each country's educational policies, especially in Japan.

The origin of progressive education, which is a pedagogical movement, could acknowledge to the new educationists such as John Locke (1632-1704), Jean-Jacques Rousseau (1712-1778), Johann H. Pestalozzi (1746-1827), Johann F. Herbart (1776-1841), and Friedrich W. A. Fröbel (1782-1852). Their ideas helped to provide a basis for the progressive education movement (Gordon and Lawton 1984). John Dewey (1859-1952) who was influenced from such new educationists became the "patron saint" (Reese 2001, p. 23) of the progressive education from the late nineteenth century to the early twentieth century in the US. The progressive education and the childcentered approach were introduced into Japanese education, especially in some private elementary schools and elementary schools attached to normal schools in the first quarter of twentieth century, and it was called "Taisho New Education" or "Taisho Free Education" (Mizuhara 2011).

In the US, the first decade of twentieth century, high school was facing its "true task, that of democratic education" (Eikenberry 1922, p. 9), therefore, the period between 1910 and 1940 was named the "High School Movement" (Goldin and Katz 1999); similarly, the "Secondary Education for All" policy was proposed by the Labour Party in 1922 (Education Advisory Committee of the Labour Party n.d.), and some government's reports on secondary education were published from 1920s through 1940s in Britain (e.g., Board of Education 1927, 1938, 1943).

As the rapid economic growth that Japan experienced during World War I created new demands in the educational system, and the changing occupational structure resulted in a situation where growing numbers of secondary education level aspired to go on for future education (Ministry of Education, Science and Culture 1980). Hence, the diversification of secondary education in these nations was triggered by increased enrollment in secondary schools between the late nineteenth and early twentieth centuries (see Table 1, 2 and 3).

In the United States, science teaching in the early twentieth century primarily focused on socialization and practical applications (Eikenberry 1922); science educators prioritized the promotion of social efficiency (Krug 1964). In 1893, 1918, and 1920, key recommendations concerning secondary education and science curricula were published by the National Education Association (NEA) in the US. In the United Kingdom, similar reports were published by the British Association for the Advancement of Science (BAAS) in 1918 and 1923, as well as by the School Masters' Association (SMA) in 1920s and 1930s. Each of these reports emphasized the notion that, 'science should be

Table 1 Numbers of high schools (public and private) form 1889-1890 to 1927-1928

\begin{tabular}{ll}
\hline Year & No. of schools reporting (No. of students) \\
\hline $1889-1890$ & $4,158(297,894)$ \\
$1899-1900$ & $7,983(630,048)$ \\
$1909-1910$ & $11,994(1,032,461)$ \\
$1919-1920$ & $16,419(2,041,308)$ \\
$1927-1928$ & $20,564(4,486,562)$ \\
\hline
\end{tabular}

(Source: Kandel, I. L. (1930). History of secondary education: A study in the development of liberal education. Boston: Houghton Mifflin, p. 449.) 
Table 2 Numbers of Secondary Schools (Grant and Efficient) recognized by the Board of Education

\begin{tabular}{ll}
\hline $1^{\text {st }}$ Oct. Year & No. of schools (No. of students) \\
\hline 1913 & $1,148(210,193)$ \\
1921 & $1,482(408,635)$ \\
1925 & $1,613(424,824)$ \\
1928 & $1,691(457,085)$ \\
1932 & $1,756(514,916)$ \\
1936 & $1,787(554,615)$ \\
1937 & $1,794(558,097)$ \\
\hline
\end{tabular}

(Source: Board of Education (1938). Report of the consultative committee on secondary education. London: His Majesty's Stationery Office, p. 91.)

Table 3 Numbers of boys' and girls' secondary schools from 1886 to 1930

\begin{tabular}{lll}
\hline Year & $\begin{array}{l}\text { No. of boys' secondary schools } \\
\text { (No. of students) }\end{array}$ & $\begin{array}{l}\text { No. of girls' secondary schools } \\
\text { (No. of students) }\end{array}$ \\
\hline 1886 & $56(10,300)$ & $7(898)$ \\
1900 & $218(78,315)$ & $52(11,984)$ \\
1910 & $311(122,345)$ & $193(56,239)$ \\
1920 & $368(177,201)$ & $514(151,288)$ \\
1930 & $557(345,691)$ & $975(368,999)$ \\
\hline
\end{tabular}

(Source: Ministry of Education, Science and Culture (1980). Japan's Modern Educational System. Tokyo: Ministry of Finance, Statistics.)

studied in more effective relation with life and things as they are in the everyday world' (Jenkins 1989, pp. 34-35). The Japan's Ministry of Education introduced general science in an attempt to reform the curriculum of boys' secondary schools taking account of the social contexts mentioned above but without teachers' enthusiasm and support to teach it.

As a result, science educators in democratic societies came to believe that science should be humanized and socialized.

\section{The meaning of general science and humanities}

Scientific subjects in secondary schools can be divided into separate sciences (for example, physics and biology) and balanced science (for example, integrated science and combined science); general science falls into the latter category. There have been historically recurring conflicts between proponents of both approaches with respect to how secondary curricula should prepare students, including those who may become scientists.

In a 1943 report from the British Board of Education, general science was defined as

an elementary course of study [...] for which the subject-matter, related wherever practicable to the everyday experience of pupils, is drawn from the whole field of Natural Science and treated as a coherent whole, so that the question of the traditional division into separate Science subjects such as Physics, Chemistry, Biology, Astronomy and Geology does not arise. (p. 108)

Rather than limit teaching to the "dehumanized materials of physics and chemistry," the BAAS (1918) advocated placing greater emphasis on the human aspects of science 
as "more of the spirit, and less of the valley of dry bones" by focusing on its history and the lives of investigators so as to, "stimulate interest in scientific greatness and its relation to modern life" (p. 140).

In the United States, the Commission on the Reorganization of Secondary Education of the NEA (1920) asserted that general science was not a substitute for any other specialized course, it would be the "science of common things" and the "science of common use" (p. 25).

According to the order of the Japan's Ministry of Education in 1931, the aims and objectives of newly integrated subject as science $(r i k a)$ is to develop the useful scientific knowledge and skills relating to students' daily lives not to fall into theoretical and academic explanation on scientific knowledge (Tokyo Kaiseikan 1939).

Therefore, general science as humanized science study is a balanced science course based on everyday concepts and common things that enables learners to grasp natural science as a coherent whole. Although Glen S. Aikenhead (2006) and James F. Donnelly (2004) defined the term "humanities" differently, both researchers nonetheless agree that humanizing school sciences promotes citizenship. In this paper, humanized science study refers to a humanistic approach to school science that promotes science for all.

\section{The case of the United States}

In the United States, a need for adequate science courses "new and more democratic" (Eikenberry 1922, p. 9.) high schools, increased drop-out rates in existing high schools, and decreased enrolment in science classes were three factors that led to the development of general science (e.g., NEA 1893; Eikenberry 1922; DeBoer 1991). In addition, "there was considerable pressure [...] to make [science] more relevant to the everyday lives of the students and to their future needs as citizens in a democratic society" (DeBoer 1991, p. 89). A lecture delivered by Harvard University President Charles. W. Eliot (1834-1926) in 1889 spurred the reorganizing of secondary education, and its effects were evident in subsequent reports published by the NEA (e.g., 1893, 1899, 1915, 1918) and by Otis W. Caldwell (1869-1947) (1914, 1915), which proposed a unified high school science course as well as a unified introductory subject (for example, physiography, physical geography or elementary science).

In 1920, the NEA Commission on the Reorganization of Secondary Education recommended inclusion of a unified general science course in the early grades of high schools. According to a survey, general science was being taught in $92 \%$ of California's 337 high schools shortly thereafter (Kellogg 1922). A subsequent survey conducted during the school year 1947-48 indicated that more than $60 \%$ of US students in the seventh (12-13 years old) and ninth grades (14-15 years old) were enrolled in general science course, whereas enrollment in eighth-grade (13-14 years old) general science and biology was more than $75 \%$ (Johnson 1950). Hence, general science was widely adopted in US high school curricula during the first half of the twentieth century.

In terms of how general science was characterized in the United States, John F. Woodhull (1857-1941) (1918) asserted that

Our experiences and our observations upon nature are not naturally differentiated under such headings as chemistry, physics, physiology, botany, etc. If we label them 
anything we may use the term general science. It is science if it is organized common sense (p. 177, italics in original).

Likewise, Eikenberry maintained that general science entails "developing the habit of scientific thinking and securing scientific information through the investigation of a series of real problems arising in practical situations in the school, the home, the playground, or in other activities" (1922, p. 77). Moreover, he insisted that general science should embody Dewey's process of scientific thinking (1922). Although Dewey was in favor of general science as a concept, he nonetheless cautioned against adopting "any method of which begins with scientific knowledge in its already-made form," and asserted that general science should aim to "get back nearer to the world in which the pupil lives, and away from a world which exists only for the scientists" (1945, p. 121). As a part of the general education of citizens (including future scientists) in a democratic society, it was necessary for science teaching in the US to become more humanized, wherein general science was proposed as an antidote (Woodhull 1918) rather than "'hodge-podge' of unrelated units of special sciences" (Frank 1926, p. 21) or as a revolt against specialization (Rudolph 2005). Thus, John M. Heffron (1995) characterized general science as "a symbol of resistance to the gradual balkanization and college orientation of the curriculum" (p. 232).

Bertha M. Clark (1919) analyzed the prefaces of 13 different books regarding general science and grouped the discipline's objectives into four categories: (1) to introduce students to a scientific study of their environment; (2) to demonstrate how that scientific work is frequently performed by social organizations rather than individuals; (3) to teach the scientific method in practice by using common things and to develop scientific points of view; and (4) to highlight the leaps and bounds in progress that can be obtained through specialization. Similarly, William R. Leker (1925) examined textbooks and literature concerning general science and grouped the field's objective's into five categories: (1) to understand, appreciate, and control one's environment; (2) to amass information that can be applied in one's industrial and social life; (3) to amass information about nature and science; (4) to prepare for higher level science courses; and (5) to promote critical thinking and problem-solving abilities. Hence, a commonality between Leker and Clark's categorizations is that general science should entail understanding science in the context of an individual's daily life, while also providing a foundation for studying science at a more advanced level. Along these lines, the NEA (1920) proposed the following seven sample topics for general science curricula: (1) combustion; (2) water; (3) air and weather; (4) light and its benefits; (5) work and energy; (6) magnetism and electricity; and (7) nature's valance of life. These topics also included subcategories such as "Light and its benefits" comprised concepts such as the visibility of objects, intensity of illumination, measurement of light, reflection, refraction, color, photography, artificial lighting, the benefits of light, and the effects of sunlight on one's health. Several scholars emphasized the importance of practical work such as experiments, observations and excursions in teaching general science. For example, with reference to Dewey's notion of scientific thinking, Eikenberry (1922) asserted that, "No generalscience course which does not rest upon a basis of careful experiment in the classroom can be considered a contribution to education" (p. 33). Likewise, Caldwell, Eikenberry and Charles J. Pieper (1915) maintained that, "Laboratory work and the experiences of home and school furnish an important basis for the course in general science" (p. iii). 
In a book containing suggestions for classroom experiments, Caldwell and Eikenberry (1926) stated that the objective of general science is to "develop a usable fund of interesting and worth-while knowledge about common things," and "to develop helpful and trustworthy habits of thinking about and of judging the common experiences which fall within the fields of science" (p. iv). The topics in Caldwell and Eikenberry's books involved phenomena that students were familiar with, which often had some commercial or civic importance. Furthermore, the NEA (1920) suggested that books be used both as reading and reference books in teaching general science.

Although Woodhull (1915) addressed the notion of a topic or project-based teaching approach, general science was conceptualized by scholars such as Woodhull, Eikenberry, and Caldwell who combined progressive education with Dewey's childcentered approach and problem-solving methods, which had been adopted by many science teachers. General science was soon taught in higher education institutions, including normal schools, and in 1916, a highly influenced journal named General Science Quarterly was launched.

John S. Richardson (1945) noted the challenges faced by general science and highlighted its weaknesses, such as the absence of a concrete definition and inadequate training for general science in teacher education programs. Regarding the latter point, Eikenberry (1922) attempted to define the precise role of general science teachers 20 years earlier, wherein he emphasized that such science educators should possess specific scientific and professional qualifications.

In summary of the case in the United States, general science emerged during the first quarter of the twentieth century supported by educational and psychological ideas such as child-centered and problem-solving approaches, and took the interests and relevance to everyday life of students into account in order to promote the intellectual development of young citizens in a democratic society.

\section{The case of the United Kingdom (primarily England and Wales)}

The committee appointed by the Prime Minister to enquire into the position on natural science in educational system of Great Britain (Thomson Committee) criticized the situation of science teaching in the early twentieth century; "the customary course [...] has become too narrow [...] the choice of subject matter is unduly restricted. Furthermore, it is out of touch with the many applications of Science. [...] the course does not satisfy the natural curiosity of the pupils" (1918, p. 53). The Thomson committee asserted the importance of "self-contained science course" up to the age of 16 . What does the "self-contained course" mean? It should be "designed so as to give special attention to those natural phenomena which are matters of everyday experience, in fine, that the Science taught in it should be kept as closely connected with human interests as possible" (1918, p. 60).

Before this report published, Richard A. Gregory (1864-1952) (1904) revised and partially rewrote Physiography originally written by Thomas H. Huxley (1825-1895), which attempts to describe "the fundamental principles of scientific education" (Huxley 1878, p. vii). According to George R. Twiss (1917), in terms of its spirit and mode of presenting methods of scientific inquiry, Huxley' book provided the first consistently organized blueprint for a general science course. Gregory (1916) published Discovery, in which he praised Huxley as a "warrior of science" (p. 10), and emphasized the importance of science 
for general education in promoting human development using rhetoric reminiscent of Huxley's (1895). Gregory asserted that general science should encompass,

more than an amorphous collection of topics from physics and chemistry, with a little natural history thrown in as a sop to biologists. It should provide for good reading as well as for educational observation and experiment; [it] should be humanistic as well as scientific (BAAS 1923, p. 209).

Traces of Huxley's Physiography are also apparent in a report published by the Thomson Committee (1918) in the context of early secondary education as an example of the self-contained science course; similarly, the Board of Education (1943) acknowledged that general science originates from the old "Physiography." Hence, the roots of general science can be traced back to the mid-nineteenth century (e.g., Jenkins 1999).

It initially proved difficult to translate the lofty ideas of general science into practical proposals in the United Kingdom (Jenkins 1989). In 1924, the Science Masters' Association (SMA) published a pamphlet concerning general science that included a syllabus, an approach that was originally taken by a publication entitled Science for All in 1916. According to the pamphlet's preface "The whole essence of General Science lies not in the syllabus, but in the interpretation of it" (SMA 1924, p. 12) and as such "General Science will not be successful unless it is treated as a whole" (SMA 1924, p.17). Nevertheless, the syllabus and its accompanying guidelines for practical work were organized in terms of topics: Section I pertained to physics and astronomy, Section II concerned chemistry and geology, and Section III covered biology.

The SMA subsequently published The Teaching of General Science in 1936; it included an identically categorized syllabus for years I - IV, although astronomy and geology were omitted. In response to the criticism of the interim report of 1936, the SMA subcommittee decided that, "depth rather than breadth should be sacrificed" (1938, p. 11). A revised version of the syllabus (The Teaching of General Science II) was published, which reintegrated astronomy and geology on an as needed basis (1938). In 1950, the SMA's Report on the Teaching of General Science was published, in which astronomy and geology were removed once again. These changes are in line with the Board of Education's (1943) assertion that, "the content or the method or the length of the course cannot be prescribed in detailed terms for any school" (p. 108). In other words, the Board's position was that the precise approach to teaching general science should be ultimately determined by science teachers themselves. A historian of science, John D. Bernal (1939) highly evaluated the philosophy of The Teaching of General Science published in 1936, on the other hand he criticized the lack of broadness and modernity of teaching contents.

Using air as an example (which may prompt students to consider concepts such as pressure, fire, balloons, and breathing), the SMA (1924) argued that eliminating barriers between physics, chemistry, and biology revealed the fundamental unity of science; nevertheless, the SMA (1936) recognized that this unity was elusive, and exists "only as an ideal in the mind of the man of science" (p. 23). Hence, the success or failure of general science in practice depends on the professional judgement of science teachers. Furthermore, topical methods (including the topic method of teaching) were proposed in an effort to break down barriers between the separate sciences (SMA 1936; 1950). 
General science, according to the SMA (1936; 1950), was a course of study and investigation rooted in the common experience of children, which does not exclude fundamental science; moreover, it focuses on general principles that are observed in nature, but does not delve into specialized subjects unless doing so "is warranted by the increasing complexity of the field of investigation" (SMA 1936, p. 30; 1950, p. 13, italics in original).

An examination of syllabi revisions spanning approximately three decades highlights the frustration experienced by the SMA committee. Despite numerous attempts to define general science, their interpretations would eventually be criticized, either with respect to the organization of subject matter, or in terms of the idea of general science itself. Based on the Thomson Committee's adherence to the principles of classical physiography, Henry S. Shelton (1939) believed that disciplines within general science should be unified; however, he criticized the SMA's criteria for excluding or including a fact or principle in every revised syllabus, which was not based on the importance of the fact or principle in the structure of human knowledge, but rather based on the particular branch of science (p. 39).

L. Connell and W. S. James (1958), on the other hand, were skeptical of the notion of general science itself, and argued that the "study of children's natural interests in phenomena provides no support for the belief that 'science is a unity"' (p. 280). Likewise, Edgar W. Jenkins (1979) pointed out that the most frequent and persistent criticism of general science concerns its mishmash of topics and the absence of coherent or adequate interpreting principles. Henry E. Armstrong (1848-1937) (1903), whose heurism was revived in the form of neo-heurism by means of the Nuffield Science Teaching Project in 1960s, regarded Huxley's physiography as "a type of the book to be avoided" (p. 86). Indeed, Connell and James (1958) asserted that, "We need a new Armstrong to restore this science teaching those qualities which it has lost sound laboratory work has gradually disappeared from the general science courses" (p. 283). It should be noted that Armstrong (1903), like Huxley, believed that science syllabi should be based on a science of daily life which include elements from the separate sciences - "the olla podrida comprehended by Huxley under physiography" (p. 222).

A survey conducted by Donald H. J. Marchant (1944) revealed that although many science teachers recognized that general science was satisfactory both culturally and educationally, it did nonetheless not provide a solid foundation for advanced studies at the sixth-form level (pre-university). General science (and social biology) consequently came to be associated with female learners and less capable or academically inclined students (Jenkins 1989); hence, it was stigmatizing and considered a subject unto itself, rather than a comprehensive course as originally intended (Layton 1984).

Despite claims that general science fails to clearly distinguish between theory and practice, its manifestation in the United Kingdom nonetheless reflected an "explicit and seminal attempt to link school science with citizenship" (Jenkins 2006, p. 198).

\section{The case of Japan}

In Japan, the central government's interventions in the field of education were stronger than in the US or the UK, and there was no significant general science movement let by science educators. Huxley's Physiography is, therefore, not the starting point for general science among Japanese science educators, although it was translated into Japanese in the nineteenth century. A unique experimental research practice could be observed 
in the previous organization of general science. The origin of general science in Japan can be traced back to Yaezo Wada (1870-1961) who had the opportunity to study in America, and was a teacher at a private secondary school. In discussing the Japanese educational context and the psychology of adolescence, Wada (1920) referenced American professor Parker, and argued that students attending boys' secondary schools should be introduced to scientific concepts in a broad sense by studying real-life problems before splitting into the separate sciences. Then he privately published a general science textbook entitled Shizen Kagaku Nyūmon (Introductory Natural Sciences) (1923). Although Wada's ideas and experimental research practices in schools could not be extended so much to other national and municipal boys' secondary schools, which were closely linked to high schools and designed to prepare students for higher education, his experimental research practice of general science at the first year of boys' secondary school seems to be institutionally realized in 1931.

In his examination of general science in US, Isaburo Kanbe (1884-1963) (1931) identified six key characteristics: (1) general science was studied prior to separate sciences; (2) individuals could study a scientific field even if they had dropped out of school; (3) general science focused on common and easy to understand concepts in order to promote interest in science among students; (4) general science was comprehensive and unified, and emphasized matter pertaining to everyday life; (5) general science aimed to provide students with scientific training; and (6) general science stressed the utilitarian value of scientific knowledge in relation to one's daily affairs. Kanbe argued that the importance of points (3)-(6) would be magnified in the context of Japanese science education.

In 1931, the Japanese Ministry of Education reorganized secondary education for boys by the "Regulations for the Enhancement of the 1899 Middle School Order", and combined a subject known as 'physics and chemistry' and a subject known as 'natural history' (that is, botany, zoology, geology, and physiology and hygiene) into a single compulsory subject named rika. Rika in boys' secondary schools comprised two balanced subjects ippan rika and oyō rika [general and applied science, respectively], in addition to separate sciences (that is, physics, chemistry, botany, geology, and physiology and hygiene). All students of boys' secondary schools were required to take general science as a first year (otsu-hyo) or first two-years (kō-hyo) prior to studying each of the separate sciences.

The science curriculum in boys' secondary schools began with the teaching of scientific knowledge in relation to students' common-sense pertaining to their daily lives and environment through ippan rika; following this, they studied the separate sciences, thereby preparing them to apply scientific concepts and identify relationships between science and human life through oyō rika. Ōyō rika was only studied by otsu-hyo curriculum at the final grade. As of 1933, most schools (196 of 294) had adopted kō-hyo (Hiroshima Kōtō Shihan Gakkō Fuzoku Chūgakkō 1933). Rika was compulsory in normal elementary schools in grades 4-6 (9-11 years old); accordingly, general science often functioned as a bridge between elementary school science and the separate sciences in the middle/upper grades of boys' secondary schools.

According to the 1931 Ministry of Education in regulations (Tokyo Kaiseikan 1939), general science should attach weight to practical observations, avoid theoretical explanations, and consider relationships between teaching materials from upper and lower 
Table 4 Topics of general science in boys' secondary schools by the Ministry of Education

Two-years course syllabus of General science ( $k \bar{o}-h y o$ ) without detailed information and no practical work

OBlossoms and fruits, seeds, shoots, flowers, roots, caules, and leaves

OFerns, algae, mushrooms, mold, and bacteria

OMorphology, dissection, physiology, and ecology of rabbits, fowls, crucian carp, frogs, and grasshoppers

OCommon minerals, rocks and soil

OAir, combustion, and heat

OWater

OAcid and base

OClothes and foods

OMusical instruments and gramophones

OMirrors and lends

OSimple machines

OHeat engines

OElectricity

OElectric current and magnetics

OElectric current and heat

One-year course syllabus of General science (otsu-hyo) without detailed information and no practical work

OBlossoms and fruits, seeds, shoots, flowers, roots, caules, and leaves

OMushrooms, mold, and bacteria

OMorphology, dissection, physiology, and ecology of rabbits, fowls, crucian carp, frogs, and grasshoppers

OCommon minerals, rocks and soil

OAir, combustion, and heat

OWater

OMusical instruments and gramophones

OMirrors and lends

OStatic electricity

(Source: Tokyo Kaiseikan (1939). Chūgakkō Kaiseikyoikuhourei. Tokyo: Tokyokaiseikan, pp.76-81.)

grades. Thus, science teachers of boys' secondary schools who taught general science were required to maintain a connection between the separate sciences (from upper and middle grades) and elementary school science, while also focusing on practical work. The 1931 regulations also listed basic topics as common things, which might pertain to students' daily lives and which were intended to assist students' understanding the application of science and relation between science and human life (see Table 4). Comparing with the US and the UK general science syllabi, the Japanese syllabus described only topics without detailed instruction manuals and there was no reference to practical work. Science teachers, therefore, could be encouraged to arrange teaching materials according to the needs of their local and school environment. This fact meant that the success or failure of general science depended on the competency and enthusiasm of science teachers. The topics listed did not adequately integrate content from the natural sciences; general science therefore came to function as a mere introduction to the separate sciences that students would study later. In addition, general science textbooks tended to lack coherence, and mixed bits of natural history with physics and chemistry. There were, nevertheless, some ambitious attempts to create a comprehensive general science textbook, such as Kanbe's.

As Table 3 shows, the rapid expanding secondary schools led to the diversity of students' ability, aptitude and future courses. The Ministry of Education reorganized the secondary curricula and enhanced science curriculum in boys' secondary school to be humanized through introduction of general science as the first step of three stepslearning in science: the first step of learning was to understand scientific knowledge pertaining to students' daily lives, native provinces and environment through ippan rika; the second one was to study all separate sciences, the third one was to understand the application of sciences and the relationship between science and human life 
through oyo rika. With the sudden introduction of general science in 1931 by the Ministry of Education without experimental research practices in national and municipal boys' secondary schools before then, many science educators struggled to comprehend and implement the changes (Kanbe 1938). At annual conferences for science educators, attendees expressed confusion regarding the organization of science lessons, about who should teach general science, and about the precise meaning of general. Given the training received by these science educators and the fact that they possessed teaching licenses in the separate sciences, this confusion regarding the concept of whole science teaching was understandable.

Some associations for secondary science educators held meetings about how to effectively teach general science, and made proposals to the Ministry of Education based on their findings. Likewise, pioneers in science teaching such as Wada (1920), Kanbe (1931; 1932), Shichizō Hori (1935), Michimasa Kōno (1935), and Hōkichi Nakagawa (1935) edited books on general science that incorporated classroom practices. These books introduced the US perspectives on general science to Japanese audiences. Nakagawa was unique, however, in that he used the UK as a point of reference, and provided suggestions for classroom practices that accounted for the Japanese context. The Ministry of Education also held seminars, lectures, and open-house lesson study on general science, and modified the curricula of Tokyo and Hiroshima Higher Normal Schools to equip future teachers with the knowledge and skills necessary to teach general science.

Despite efforts by the Ministry of Education and Japanese science educators to implement general science, these initiatives lacked a strong theoretical basis when compared to the US. Moreover, general science as humanized science study did not emerge in Japan based on a push from science educators themselves except a few cases in contrast to the UK, but through a government mandate. General science was removed from the secondary school science curriculum for boys after only ten years and by 1942, science courses were categorized as belonging to either the physical sciences (busshō) or biology.

\section{Discussion-what can we learn from the history of general science and its movement?}

Through adopting the triangulation of cultures approach in historical context, several similarities and differences between Japan and the two western countries could be observed, and the cultural identity can be highlighted and represented.

General science was implemented in US, British, and Japanese secondary education during the first half of the twentieth century. General science can be regarded as a resulting from the intensity of argument about the place of humanized science study for secondary schools in their respective societies. Doubts were raised, however, regarding its effectiveness in preparing students for specialized science courses. In addition, the introduction and implementation of general science differed between countries. Whereas general science in the US and the UK was adopted by science educators willfully and studied by both genders as either an introduction or matriculation subject, there was no push by Japanese science educators except a few experimental research cases for general science, it was studied only by boys, and was deemed unsuitable as a matriculation subject. An examination of the history of general science nonetheless 
provides insights into (1) important factors for innovation in science education; (2) how students learn science in secondary schools; and (3) the organization and management of science curricula by policymakers, schools, and teachers.

Regardless of time and national context, innovations in science education have always been accompanied by debate concerning the kind of science that should be taught, the reasons students should learn science, and science education's overall purpose. In general, science education in schools has had two aims: one is to promote scientific literacy among young citizens (including prospective scientists) or personal development; another is to provide a foundation for them to learn more advanced studies. There would seem to be an essential tension between two aims (e.g., Layton 1986, Millar 2006). However, science traditionally taught in schools (particularly in secondary and postcompulsory contexts) was pure and abstract (Roscoe 1906), and therefore disassociated from social issues and human values. In order to establish and maintain a firm position in the secondary school curricula it was necessary for science to appear wholly academic and distant from industry or everyday life, as was the case with classical subjects and mathematics, especially in the UK (Young 1986). The NEA, SMA, and Japanese Ministry of Education outlined the aims of science education in their respective societies, and in doing so established that general science was essential to accomplishing science education's underlying goal. Ultimately, the aforementioned entities hoped that students would develop an interest in science and become scientifically informed citizen in their respective societies, capable of applying scientific concepts to their own lives.

In the early twentieth century, policymakers and science educators in these countries believed that general science was an essential component of science curricula and therefore promoted it as a humanized program of study intended to function as an introductory subject or bridge to separate sciences. However, science teachers continued to perceive the supply of future scientists to be the primary objective of secondary science education. Accordingly, separate sciences remained purely academic in nature (Young 1986). In addition, science teachers often encountered difficulties in teaching general science since it was designed to be primarily taught by a single teacher; some could not grasp the concept of general science itself and preferred to teach specialized sciences; others simply lacked a broad enough understanding of science to teach it.

Despite Eikenberry and Woodhull's insistence that general science should focus on methods rather than content and the SMA's emphasis on the importance of professional judgement in interpreting the syllabus, science educators, nonetheless, continued to debate the selection of subject matter and its manner of integration. Discussions concerning general science were against the backdrop of a new, democratic society and, therefore, focused on the discipline's role in creating scientifically informed citizens; hence, attempts were made to develop science curricula based on students' experiences in order to create a sense of personal relevancy. General science was also embedded in arguments regarding equality between boys and girls and equity of opportunities for students of varying abilities. Thus, an examination of the general science movement provides a historical overview of the perceived importance of secondary curricula among policymakers and educators in terms of context (for example, social, communal, personal and school), content (for example, academic or applied, depth, and relevance), and methods/process (for example, quality and quantity of practical work, 
new approaches such as argumentations and role-playing). Establishing the precise aims of science education should receive the highest priority, which entails determining why science should be taught and what students ought to gain from leaning about it.

However, who should dictate the direction and future of science education? The 47member commission on the Reorganization of Secondary Education formed by the NEA in 1920 included 19 secondary school teachers, five pre-service teachers of Columbia's Teachers College, five normal school teachers, and five university professors. It was, therefore, reflective of teacher experiences, and its findings could be deemed credible. Members of the SMA possessed similar professional experience and their revised general science syllabi were based on sound pedagogical practices and observations. Even though Japan's implementation of general science was mandated by the Ministry of Education, science educators were nevertheless involved in research and development of teaching materials and approaches by means of lesson study as one of traditional professional cultures of teachers (Isozaki 2015). Therefore, through the comparison of general science and its movement in three countries, we could observe one historical example of science teachers' accumulated wisdom and expertise as professional cultures in each country.

The case of general science and its movement in Japan, the US, and the UK demonstrates that, "a profession can be interpreted as a means of controlling an occupation, in this case of defining what counts as 'teaching science"' (Layton 1984, p. viii). Although each nation's attitude toward education is different, the history presented here confirms that innovations in science education can occur when relevant educators are actively involved in the process. Furthermore, science educators in knowledge-based societies must understand their students' daily lives and what will be important for them in the future, so as to obtain and teach appropriate subject knowledge (that is, connective specialization (Young and Glanfield 1998)). From the historical viewpoint, the case of general science and its movement clearly exemplify that the role of science teachers is a very important vehicle for the innovation of science education.

\section{Conclusion}

Science is an essential component of the school curriculum in secondary education level, and should be taught by unifying and harmonizing the purposes of school education as a whole. Despite its assured place in curricula, the reason why science is considered important, the aims and objectives of science education, the debate on what type of science is suitable for all students including future scientists, and the nature of the science being taught have changed continuously according to time and context.

As DeBoer (2000) and Jenkins (2006) referred to general science for thinking about scientific literacy and science for citizens, using the comparative approach in historical context, this case study of general science and its movement should prompt readers to reconsider why science is taught, which of its forms are best suited to producing citizens well-versed in science, and how to humanize science without comprising the academic respectability required by professional communities and institutions of higher education. 


\section{Acknowledgement}

I wish to thank Professor Justin Dillon, the University of Bristol for significant comments and editorial assistance.

Received: 27 January 2016 Accepted: 10 April 2016

Published online: 12 May 2016

\section{References}

Aikenhead, G. S. (2006). Science education for everyday life: Evidence-based practice. New York: Teachers' College Press. Armstrong, H. E. (1903). The teaching of scientific method and other papers on education. London: Macmillan and Co. Bernal, J. D. (1939). The social function of science. London: George Routledge and Sons.

Board of Education. (1927). Report of the consultative committee on the education of the adolescent. London: His Majesty's Stationery Office.

Board of Education. (1938). Report of the consultative committee on secondary education: With special references to grammar schools and technical high schools. London: His Majesty's Stationery Office.

Board of Education. (1943). Curriculum and examinations in secondary schools: Report of the committee of the secondary school examinations council appointed by the president of the Board of Education in 1941. London: Her Majesty's Stationery Office.

British Association for the Advancement of Science. (1918). Report of the British Association for the Advancement of Science 1917. London: John Murray.

British Association for the Advancement of Science. (1923). Report of the (Hull) meeting, 1922. London: John Murray.

Briggs, A. (1972). The study of the history of education. History of Education, 1(1), 5-22.

Caldwell, O. W., Smith, J. H., Spicer, C. E., Evans, A. W., \& Butler, W. M. (1914). Preliminary report of the committee on a unified high school science course. School Science and Mathematics, 14(2), 166-168.

Caldwell, O. W., Smith, J. H., Spicer, C. E., Evans, A. W., \& Butler, W. M. (1915). Report of the central association of science and mathematics teachers committee on the unified high school science course. School Science and Mathematics, 15(4), 344-346.

Caldwell, O. W., Eikenberry, W. L., \& Pieper, C. J. (1915). A laboratory manual for work in general science. Boston: Ginn and Company.

Caldwell, O. W., \& Eikenberry, W. L. (1926). Elements of general science with experiments. Boston: Ginn and Company.

Clark, B. M. (1919). Aims and purposes of general science. General Science Quarterly, 4(1), 291-295.

Connell, L., \& James, W. S. (1958). General science today. The School Science Review, 39, 277-285.

DeBoer, G. E. (1991). A history of ideas in science education: Implications for practice. New York: Teachers College Press.

DeBoer, G. E. (2000). Scientific literacy: Another look at its historical and contemporary meaning and its relationship to science education reform. Journal of Research in Science Teaching, 37(6), 582-601.

Dewey, J. (1945). Method in science teaching. Science Education, 29(3), 119-123. (Original: General Science Quarterly, 1(1), 1916.)

Donnelly, J. F. (2004). Humanizing science education. Science Education, 88, 762-784

Education Advisory Committee of the Labour Party by R. H. Tawney (n.d.). Secondary education for all: A policy for labour. London: Labour party.

Eikenberry, W. L. (1922). The teaching of general science. Chicago: The University of Chicago Press.

Eisenstadt, S. N. (1996). Japanese civilization: A comparative view. Chicago: The University of Chicago Press.

Frank, J. O. (1926). How to teach general science: Notes and suggestions of practical aid to every general science teacher (new ed.). Philadelphia: P. Blakiston's Son \& Co.

Gregory, R. A. (1904). Physiography: An introduction to the study of nature. London: Macmillan and Co. (Revised and partly rewritten. Original: Huxley, T. H. Physiography: An introduction to the study of nature.).

Gregory, R. A. (1916). Discovery: Or, the spirit and service of science. London: Macmillan and Co.

Goldin, C., \& Katz, L. F. (1999). Human capital and social capital: The rise of secondary schooling in America, 1910-1940. Journal of International History, XXIX, 4, 683-723.

Gordon, P., \& Lawton, D. (1984). A guide to English educational terms. London: Basford Academic and Educational Ltd.

Heffron, J. M. (1995). The knowledge most worth having: Otis W. Caldwell (1869-1947) and the rise of the general science course. Science \& Education, 4, 227-252.

Hirakawa, S. (2010). Nihongo ha ikinobiruka (Can Japanese survive?) [in Japanese]. Tokyo: Kawadebooks.

Hiroshima Kōtō Shihan Gakkō Fuzoku Chūgakkō (Hiroshima Higher Normal School attached Boys' Secondary School). (1933). Kaisei Chügakkō sekoukisoku: Jisshijyoukyou chousa (Revised syllabus of revised middle school order: A survey of implementation status) [in Japanese]. Hiroshima: Hiroshima Kōtō Shihan Gakkō Fuzoku Chūgakkō.

Hobsbawm, E. J. (1999). Industry and empire: From 1750 to the present day (revised ed.). London: Penguin.

Hori, S. (1935). Ippan Rika no kyouiku (Education of general science) [in Japanese]. Tokyo: Toyotosho.

Huxley, T. H. (1878). Physiography: An introduction to the study of nature (2nd ed.). New York: D. Appleton \& Company.

Huxley, T. H. (1895). Science and Education. London: Macmillan and Co.

Isozaki, T. (2014). The organisation and the recontextualization of rika (school science) education in the second half of the nineteenth century in Japan. Science \& Education, 23(5), 1153-1168.

Isozaki, T. (2015). Lesson study research and practice in science classrooms. In R. Gunstone (Ed.), Encyclopedia of science education (pp. 615-618). Dordrecht: SpringerReference.

Jenkins, E. W. (1979). From Armstrong to Nuffield: Studies in twentieth-century science education in England and Wales. London: John Murray.

Jenkins, E. W. (1989). Process in science education: An historical perspective. In J. Wellington (Ed.), Skills and process in science education: A critical analysis (pp. 21-46). London: Routledge.

Jenkins, E. W. (1999). School science, citizenship and the public understanding of science. International Journal of Science Education, 21(7), 703-710.

Jenkins, E. W. (2006). School science and citizenship: Whose science and whose citizenship? The Curriculum Journal, 17(3), $197-211$. 
Johnson, P. G. (Ed.). (1950). The teaching of science in public high school: An inquiry into offerings, enrollments, and selected teaching conditions, 1947-1948 (Bulletin, 1950, No.9). Washington, DC: U. S. Government Printing Office. U. S. Office of Education.

Kaiseikan, T. (1939). Chügakkō Kaiseikyoikuhourei (Revised middle school order) [in Japanese]. Tokyo: Tokyo Kaiseikan. Kanbe, I. (1931). Ippan rika kyouiku-hou: General science (The theory of general science: General science) [in Japanese]. Tokyo: Toyotosho.

Kanbe, I. (1932). Ippan rika no jissai: General science (The practice of general science: General science) [in Japanese]. Tokyo: Toyotosho. Kanbe, I. (1938). Nippon rika kyouiku hattatsu-shi (History of science education in Japan) [in Japanese]. Tokyo: Keibunsha. Kandel, I. L. (1930). History of secondary education: A study in the development of liberal education. Boston: Houghton Mifflin. Kawada, J. (2001). Beyond cultural relativism and globalism: A proposal to deepen cultural awareness through "Trialogues", UN University International Conference on the Dialogue of Civilizations, held in Kyoto 3 August 2001 (http://archive. unu.edu/dialogue/papers/Kawada-abst-cs.pdf).

Kawada, J. (2006). Bunkajinruigaku toha nanika (What is Cultural Anthropology?) [in Japanese with English abstract]. Bunkajinruigaku (Japanese Journal of Cultural Anthropology), 71(3), 331-346.

Kawada, J. (2008). Bunka no sankaku sokuryo: Kawada Jyunzo Kouenshu (The triangulation of cultures: Essays by Junzo Kawada) [in Japanese]. Kyoto: Jinbunshoin.

Kellogg, W. S. (1922). A survey of the status of general science in California. General Science Quarterly, 6(2), 373-383.

Köno, M. (1935). Ippan rika no honshitsu to sono jisshi-hou (The nature of general science and its practice) [in Japanese]. Tokyo: Shubunkan.

Krug, E. A. (1964). The shaping of the American high school (Vol. 1). New York: University of Wisconsin Press.

Layton, D. (1984). Interpreters of science: A history of the Association for Science Education. London: John Murray.

Layton, D. (1986). Science education and values education - an essential tension. In J. Brown, A. Cooper, T. Horton, F. Toates, \& D. Zeldin (Eds.), Science in Schools (pp. 110-120). Milton Keynes: Open University Press.

Leker, W. R. (1925). The articulation of general science with the special science. General Science Quarterly, 9(3), 158-173.

Marchant, D. H. J. (1944). An inquiry into the present position of the teaching of general science in secondary schools (August 1943). The School Science Review, 25, 239-257.

Millar, R. (2006). Twenty first century science: Insights from the design and implementation of s scientific literacy approach in school science. International Journal of Science Education, 28(13), 1499-1521.

Ministry of Education, Science and Culture. (1980). Japan's Modern Educational System. Tokyo: Ministry of Finance.

Mizuhara, K. (2011). History of national curriculum standards reform in Japan: Blueprint of Japanese citizen character formation. Sendai: Tohoku University Press.

Nakagawa, H. (1935). Rika-kyouiku no kakushin (The innovation of science education) [in Japanese]. Tokyo: Shubunkan. National Education Association. (1893). Reorganization of the committee on secondary studies. Washington, D.C: GPO

National Education Association. (1899). Joint session of secondary and higher department: Repot of the committee on college entrance requirements. Address and Proceedings, 38, 625-630.

National Education Association. (1915). Preliminary report of the biology sub-committee (on organization of secondary education) of National Education Association. School Science and Mathematics, 15(1), 44-53.

National Education Association. (1918). Cardinal principles of secondary education: A report of the commission on the reorganization of secondary education (U.S. Bureau of Education, Bulletin No. 35). Washington, D.C.: GPO.

National Education Association. (1920). Reorganization of science in secondary schools: A report of the commission on the reorganization of secondary education (U.S. Bureau of Education, Bulletin No. 26). Washington, D.C.: GPO.

Ogawa, M. (2015). Rika. In R. Gunstone (Ed.), Encyclopedia of science education (p. 840). Dordrecht: SpringerReference.

Reese, W. J. (2001). The origin of progressive education. History of Education Quarterly, 41(1), 1-24.

Richardson, J. S. (1945). Trends, deficiencies, and challenges related to general science. School Science and Mathematics, 45(3), 202-210.

Roscoe, H. E. (1906). The life and experiences of Sir Henry Enfield Roscoe. London: Macmillan.

Rudolph, J. L. (2005). Turning science to account: Chicago and the general science movement in secondary education, 1905-1920. Isis, 96, 353-389.

Science Masters' Association. (1924). General science: Introduction, outline of a course, suggested practical work, and specimen papers. London: John Murray.

Science Masters' Association. (1936). The teaching of general science. London: John Murray.

Science Masters' Association. (1938). The teaching of general science II. London: John Murray.

Science Masters' Association. (1950). Report on the teaching of general science. London: John Murray.

Shelton, H. S. (1939). The theory and practice of general science. London: John Murray.

Thomson Committee. (1918). Report of the committee appointed by the prime minister to enquire into the position on natural science in the educational system of Great Britain. London: His Majesty's Stationery Office.

Twiss, G. R. (1917). A textbook in the principles of science teaching. New York: Macmillan.

Wada, Y. (1920). Chügakkō ni okeru shizenkagaku no kaizen (Improvement of natural sciences education in boys' secondary schools) [in Japanese]. Tokyo: Tokyo-furitsu dai go chūgakkō nai kenkyūkai (The committee of the Tokyo-fifth boys' secondary school).

Wada, Y. (1923). Shizen kagaku nyümon (Introductory natural sciences) [in Japanese]. Wada. Y. (self-publishing).

Woodhull, J. F. (1915). Science teaching by projects. School Science and Mathematics, 15, 225-232.

Woodhull, J. F. (1918). The teaching of science. New York: Macmillan.

Young, M. F. (1986). The schooling of science. In J. Brown, A. Cooper, T. Horton, F. Toates, \& D. Zeldin (Eds.), Science in schools (pp. 181-197). Milton Keynes: Open University Press.

Young, M., \& Glanfield, K. (1998). Science in post-compulsory education: Towards a framework for a curriculum of the future. Studies in Science Education, 32(1), 1-20. 